\title{
Antihyaluronidase and Alkaline Phosphatase (ALP) Activities of Medicinal Plants to Combat Echis carinatus Venom- Induced Toxicities
}

\author{
Syeda Fatima, ${ }^{1}$ Nazia Aslam, ${ }^{1}$ Sofia Khalid, ${ }^{1}$ Kalim Ullah, ${ }^{2}$ Khizar Abbas, ${ }^{3}$ Shahzad Hussain, ${ }^{4}$ \\ Syed Sajid Hussain Shah, ${ }^{5}$ Zia-Ur-Rahman Qureshi, ${ }^{6}$ Mughal Qayum, \\ and Muhammad Hassham Hassan Bin Asad ${ }^{8}$ \\ ${ }^{1}$ Department of Environmental Sciences, Fatima Jinnah Women University, Rawalpindi, Pakistan \\ ${ }^{2}$ Department of Zoology, Kohat University of Science and Technology (KUST), Kohat, Pakistan \\ ${ }^{3}$ Department of Pharmacognosy, Faculty of Pharmacy, B.Z. University, Multan, Pakistan \\ ${ }^{4}$ Drugs Control \& Traditional Medicines Division, National Institute of Health, Islamabad, Pakistan \\ ${ }^{5}$ Department of Environmental Sciences, COMSATS University Islamabad, Abbottabad Campus, 22060 KPK, Pakistan \\ ${ }^{6}$ Department of Pharmacy, SBK Women University, Quetta, Baluchistan, Pakistan \\ ${ }^{7}$ Department of Pharmacy, Kohat University of Science and Technology (KUST), Kohat, Pakistan \\ ${ }^{8}$ Department of Pharmacy, COMSATS University Islamabad, Abbottabad Campus, 22060 KPK, Pakistan
}

Correspondence should be addressed to Muhammad Hassham Hassan Bin Asad; hasshamasad@yahoo.com

Received 31 October 2020; Revised 6 March 2021; Accepted 11 March 2021; Published 17 March 2021

Academic Editor: Jane Hanrahan

Copyright (C) 2021 Syeda Fatima et al. This is an open access article distributed under the Creative Commons Attribution License, which permits unrestricted use, distribution, and reproduction in any medium, provided the original work is properly cited.

Snakebite is one of the most neglected diseases of developing countries. Deaths due to snakebite envenoming are quite high in Pakistan, and many deaths are caused by Echis carinatus envenomation. Traditional use of medicinal plants against snakebites is a common practice in Pakistan due to countless benefits. The current study was performed with the objective to evaluate eighteen Pakistani medicinal plants inhibitory potential against hyaluronidase and alkaline phosphatase enzymes of Pakistani Echis carinatus venom. Hyaluronidase activity $(0.2-1.6 \mathrm{mg} / 0.1 \mathrm{~mL})$ and alkaline phosphatase activity $(0.1-0.8 \mathrm{mg} / 0.1 \mathrm{~mL})$ were measured in dose-dependent manner. Crude methanolic extracts of medicinal plants were used for in vitro investigation of their inhibitory activity against toxic enzymes. All active plants were fractioned using different solvents and were again analyzed for inhibitory activity of same enzymes. Results indicated all plants were able to neutralize hyaluronidase that Swertia chirayita (Roxb. ex Flem.) Karst., Terminalia arjuna Wight and Arn, Rubia cordifolia Thumb., and Matthiola incana (L.) R.Br. inhibited maximum hyaluronidase activity equivalent to standard reference $(p>0.5)$. Pakistani medicinal plants are dense with natural neutralizing metabolites and other active phytochemicals which could inhibit hyaluronidase activity of Pakistani Echis carinatus venom. Further advanced studies at molecular level could lead us to an alternative for envenoming of Pakistani Echis carinatus venom.

\section{Introduction}

Venomous snakes are among the most feared animals on planet earth [1]. Snakebite is a common public health problem worldwide which not only cause disabilities is the victims but also results in huge number of deaths annually [2]. According to the World Health Organization (WHO), snakebite injury has been declared as "disease of poverty" as it is observed to effect mostly in rural communities of third world countries [3]. Epidemiological data showed that over 2.5 million snakebites occur annually resulting in 125,000 deaths [4-6]. Pakistan is among the highest snakebiteaffected countries of Asia with 40,000 envenoming and 8,200 deaths annually [7]. Venomous snakes have been grouped among four major families containing more than 200 venomous snake species worldwide [8]. Snakebite 
TABLE 1: Description of selected indigenous medicinal plants having neutralizing potential against snakebite.

\begin{tabular}{|c|c|c|c|c|c|}
\hline Sr. no. & Botanical names of selected medicinal plants & Family & Parts used & Voucher number & References \\
\hline 1 & Adiantum capillus-veneris $\mathrm{L}$. & Adiantaceae & Whole plants & R.R. Stewart F.W. Pak. 4(2) & {$[24]$} \\
\hline 2 & Albizia lebbeck (L.) Benth. & Mimosaceae & Seeds & R.R. Stewart F.W. Pak. 381(9) & {$[24]$} \\
\hline 3 & Althaea officinalis L. & Malvaceae & Roots & R.R. Stewart F.W. Pak. 477(6) & {$[25]$} \\
\hline 4 & Calotropis procera W. T. Aiton & Asclepiadaceae & Flowers & R.R. Stewart F.W. Pak. 566(6) & {$[26]$} \\
\hline 5 & Citrullus colocynthis (L.) Schrad. & Cucurbitaceae & Fruits & R.R. Stewart F.W. Pak. 702(10) & {$[24]$} \\
\hline 6 & Curcuma longa L. & Zingiberaceae & Rhizome & R.R. Stewart F.W. Pak. 66(3) & {$[27]$} \\
\hline 7 & Eclipta prostrata $\mathrm{L}$ & Asteraceae & Whole plants & R.R. Stewart F.W. Pak. 743(5) & {$[28]$} \\
\hline 8 & Eugenia jambolana (Willd. ex O. Berg) & Myrtaceae & Seeds & R.R. Stewart F.W. Pak. 504(2) & [29]. \\
\hline 9 & Fagonia cretica L. & Zygophyllaceae & Leaves and twigs & R.R. Stewart F.W. Pak. 433(2) & {$[30]$} \\
\hline 10 & Matthiloa incana (L.) R.Br. & Brassicaceae & Seeds & R.R. Stewart F.W. Pak. 322(2) & {$[31]$} \\
\hline 11 & Momordica charantia L. & Cucurbitaceae & Fruits & R.R. Stewart F.W. Pak. 706(1) & {$[32]$} \\
\hline 12 & Trichodesma indicum (L.) R. Br. & Boraginaceae & Leaves & R.R. Stewart F.W. Pak. 604(3) & [33] \\
\hline 13 & Psoralea corylifolia $\mathrm{L}$. & Fabaceae & Seeds & R.R. Stewart F.W. Pak. 418(1) & {$[34]$} \\
\hline 14 & Rubia cordifolia Thumb. & Rubiaceae & Roots & R.R. Stewart F.W. Pak. 689(4) & {$[24]$} \\
\hline 15 & Sapindus mukorossi Gaertn. & Sapindaceae & Fruits & R.R. Stewart F.W. Pak. 463(3) & {$[24]$} \\
\hline 16 & Swertia chirayita (Roxb. ex Flem.) Karst. & Gentianaceae & Stems & R.R. Stewart F.W. Pak. 561(4) & {$[35]$} \\
\hline 17 & Terminalia arjuna (DC) Wight and Arn & Combretaceae & Bark & R.R. Stewart F.W. Pak. 502(4) & {$[31]$} \\
\hline 18 & Lepidium sativum $\mathrm{L}$. & Brassicaceae & Whole plants & R.R. Stewart F.W. Pak. 319(4) & [36] \\
\hline
\end{tabular}

envenoming results in minor as well as major consequences depending on the venom of particular snake species. Effects of envenoming include pain, edema, hypotension, necrosis, cardiac arrest, paralysis, mucus discharge, bleeding gums, bleeding wounds, hematuria, and eventually death $[9,10]$.

Venomous snakes of Pakistan are mostly from Elapidae and Viperdae family [11]. One of the most toxic viper Echis carinatus, also known as saw-scaled viper, is found in Ashtola Island of Makran (Baluchistan) and deserts of Thar (Sindh) and Cholistan (Punjab), Pakistan. Echis carinatus snake has around $0.6 \mathrm{~m}$ length, flat body, pointed tail, and is known as a true viper $[7,12]$. Echis carinatus envenoming effects anticoagulant or procoagulant activity due to presence of active enzymes in its venom which in turn disturbs the hemostatic system $[13,14]$. Envenomation of Echis also cause local tissue damage and cell necrosis by the synergistic effect of hydrolytic enzymes hyaluronidases, phospholipases $A_{2}$, and proteases [10]. Hyaluronidase enzymes of snake venom are known as spreading factors as they attack on glycosidic linkage of hyaluronic acid and release small sugar molecules such as chondroitin and chondroitin sulfates which result in destruction of extracellular matrix [15]. Alkaline phosphatases (ALPases) are very poisonous enzymes as they can nonspecifically hydrolyze phosphate esters [16]. ALPase produces adenosine which induces miscellaneous hazardous effects like hypertention, cardiotoxitiy, redness, inflammation, antiplatelet aggregation, renal failure, unconsciousness, pain, and analgesia [17].

An estimation by WHO states that more than $80 \%$ of the world population rely on herbal-based traditional medicines for treatment of different ailments [18]. Medicinal plants have vital role in modern age drugs and folk medicines as they have various metabolites having antimicrobial, antiasthmatic, antiallergic, antidiabetic, and antisnake venom prop- erties. In recent few decades, screening of medicinal plant materials has been considered important due to its curative properties against numerous diseases including snakebite. Nowadays, attempts are being made by different health investigators to produce a plant-based alternative instead of antiserum [19]. Pakistan has rich plant diversity, and most of rural communities depend on local medicinal flora for health-related issues. The present study is based on traditionally used indigenous medicinal plants inhibitory potential against hyaluronidases and alkaline phosphatase enzymes present in Pakistani Echis carinatus venom.

\section{Materials and Methods}

2.1. Echis carinatus Venom. Echis carinatus lyophilized venom was provided by the National Institute of Health, Islamabad, Pakistan. It was kept in sterilized light resistant bottle and was stored at $4-8^{\circ} \mathrm{C}$. Venom concentration was used in terms of dry weight.

2.2. Chemical Reagents. All the chemicals for the present study were purchased from Merck and were of analytical grade.

2.3. Collection of Medicinal Plants. Medicinal plants selected for the current study were reported previously for therapeutic properties against snakebite. Plants were collected from different regions of Pakistan, whereas few of them were purchased from Pansara store, Naswari Baazar, Rawalpindi. After collection, plants were identified by expert botanist, and voucher specimen was deposited in herbarium of Institute of Pure and Applied Biology, BZU, Multan, Pakistan. List of medicinal plants is summarized in Table 1. 


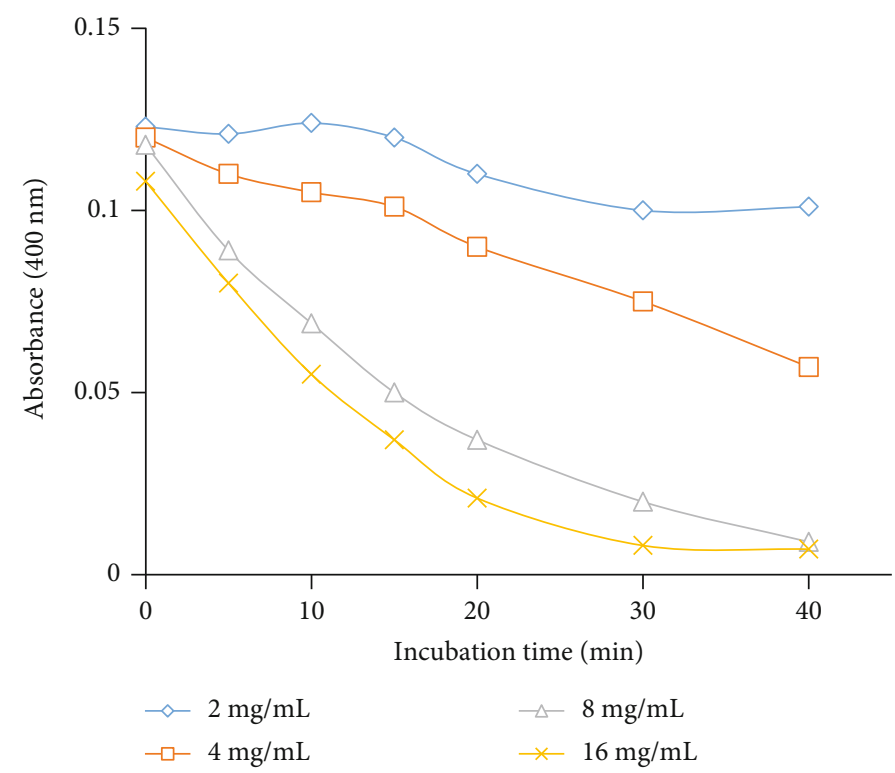

Figure 1: Effects of incubation time $\left(37^{\circ} \mathrm{C}\right)$ on hyaluronidase activity at different venom concentrations of Pakistani Echis carinatus venom.

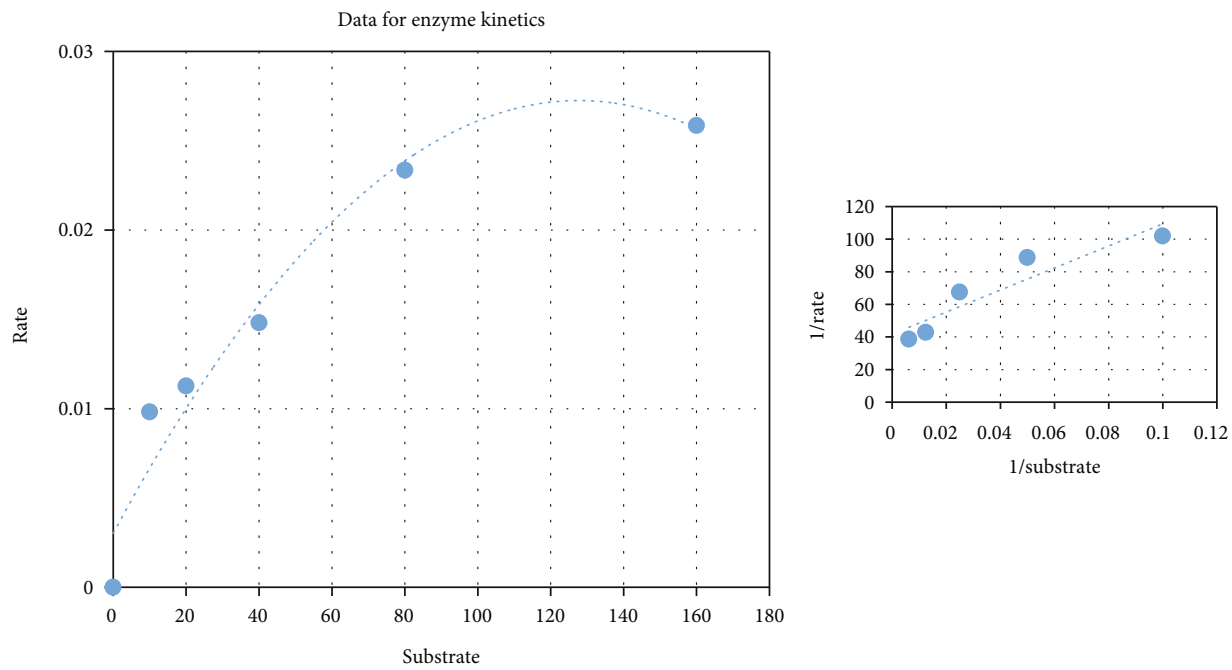

FIGURE 2: Michaelis-Menten kinetics data obtained for optimization of hyaluronidase enzyme of Pakistani Echis carinatus venom.

2.4. Plant Material Extraction. Shade dried plants (part) were chopped and subjected to simple maceration process. Methanol was used as solvent, and dried powder of desired part(s) of plant was soaked in the solvent. All soaked plants were kept at ambient temperature for about a month. Two-way filtration was done firstly by using normal filter paper and then with Whatman filter paper 41. After that, the solvent was evaporated to obtain extracts which were stored for further research [20].

2.5. Hyaluronidase Assay. The enzymatic assay of Echis carinatus hyaluronidase enzyme was performed by using method of Pukrittayakamee et al. [21] with slight modification. Briefly, the assay mixture contained acetate buffer $(0.2 \mathrm{M}$ sodium acetate-acetic acid, $\mathrm{pH} 5.0$, containing $0.15 \mathrm{M} \mathrm{NaCl}$ ), $50 \mu \mathrm{g}$ of hyaluronic acid $(0.5 \mathrm{mg} / \mathrm{mL}$ in buffer), and enzymes in a final volume of $1.0 \mathrm{~mL}$. The mixture was incubated for 15 minutes at $37^{\circ} \mathrm{C}$, and the reaction was quenched by the addition of $2 \mathrm{~mL}$ of $2.5 \% \mathrm{CTAB}$ in $2 \% \mathrm{NaOH}$. The absorbance was read at $400 \mathrm{~nm}$ (within ten minutes) against a control solution containing $1 \mathrm{~mL}$ of the same buffer and $2 \mathrm{~mL}$ of $2.5 \% \mathrm{CTAB}$ in $2 \% \mathrm{NaOH}$. Percentage of the remaining hyaluronic acid was considered as turbidity-reducing activity taking absorbance of sample with no enzyme added as $100 \%$. One unit was defined as the amount of enzyme that induced 50\% turbidity reduction. Kinetics data to optimize the hyaluronidase assay were also obtained $[22,23]$. To measure medicinal plants neutralizing potential, $(0.8 \mathrm{mg})$ extracts were preincubated with venom for $15 \mathrm{~min}$ at $37^{\circ} \mathrm{C}$.

2.6. Alkaline Phosphatase Assay. Reaction mixture was prepared by mixing $0.5 \mathrm{~mL}$ of $0.5 \mathrm{M}$ glycine buffer $(\mathrm{pH}=8.5)$, $0.5 \mathrm{~mL}$ of $0.01 \mathrm{M}$ p-nitrophenyl phosphate, and $0.3 \mathrm{~mL}$ of $0.01 \mathrm{M} \mathrm{MgSO}_{4}$. Subsequently, venom $(0.1-0.8 \mathrm{mg} / 0.1 \mathrm{~mL})$ 
TABLE 2: Inhibitory potentials of indigenous medicinal plants against hyaluronidase activity of Pakistani Echis carinatus venom.

\begin{tabular}{|c|c|c|c|c|}
\hline Sr. No. & Name of material used & Absorbance & Percentage protection (\%) & $p$ value \\
\hline 1 & Echis carinatus & $0.110 \pm 0.006$ & $0^{* *}$ & $p<<0.001$ \\
\hline 2 & Saline (control) & $0.210 \pm 0.005$ & $100^{*}$ & $p>0.5$ \\
\hline 3 & Adiantum capillus-veneris $\mathrm{L}$. & $0.165 \pm 0.005$ & $61^{* *}$ & $0.5>p>0.1$ \\
\hline 4 & Albizia lebbeck (L.) Benth. & $0.167 \pm 0.001$ & $63^{* *}$ & $0.5>p>0.1$ \\
\hline 5 & Althaea officinalis L. & $0.111 \pm 0.001$ & $1^{* *}$ & $p<<0.001$ \\
\hline 6 & Calotropis procera W. T. Aiton & $0.128 \pm 0.05$ & $20^{* *}$ & $0.1>p>0.02$ \\
\hline 7 & Citrullus colocynthis (L.) Schrad. & $0.129 \pm 0.006$ & $21^{* *}$ & $0.1>p>0.02$ \\
\hline 8 & Curcuma longa L. & $0.083 \pm 0.001$ & $-30^{* *}$ & $p<<0.001$ \\
\hline 9 & Eclipta prostrata $\mathrm{L}$. & $0.171 \pm 0.005$ & $68^{* *}$ & $0.5>p>0.1$ \\
\hline 10 & Eugenia jambolana (Willd. ex O. Berg) & $0.088 \pm 0.006$ & $-24^{* *}$ & $p<<0.001$ \\
\hline 11 & Fagonia cretica L. & $0.174 \pm 0.001$ & $71^{* *}$ & $0.5>p>0.1$ \\
\hline 12 & Matthiola incana (L.) R.Br. & $0.187 \pm 0.001$ & $86^{*}$ & $p>0.5$ \\
\hline 13 & Momordica charantia L. & $0.132 \pm 0.002$ & $24^{* *}$ & $0.1>p>0.02$ \\
\hline 14 & Trichodesma indicum (L.) R. Br. & $0.119 \pm 0.01$ & $10^{* *}$ & $p<<0.001$ \\
\hline 15 & Psoralea corylifolia $\mathrm{L}$. & $0.159 \pm 0.02$ & $54^{* *}$ & $0.5>p>0.1$ \\
\hline 16 & Rubia cordifolia thumb. & $0.188 \pm 0.02$ & $87^{*}$ & $p>0.5$ \\
\hline 17 & Sapindus mukorossi Gaertn. & $0.137 \pm 0.002$ & $30^{* *}$ & $0.5>p>0.1$ \\
\hline 18 & Swertia chirayita (Roxb. ex Flem.) Karst. & $0.190 \pm 0.01$ & $89^{*}$ & $p>0.5$ \\
\hline 19 & Terminalia arjuna (DC) Wight and Arn & $0.189 \pm 0.03$ & $88^{*}$ & $p>0.5$ \\
\hline 20 & Lepidium sativum L. & $0.155 \pm 0.002$ & $50^{* *}$ & $0.5>p>0.1$ \\
\hline 21 & Rutin trihydrate (standard hyaluronidase inhibitor) & $0.191 \pm 0.01$ & $90^{* * *}$ & Selected to compare \\
\hline
\end{tabular}

Note: ${ }^{*}$ represents $p$ values nonsignificantly different from standard reference. ${ }^{* *}$ represents $p$ values significantly different from standard reference. ${ }^{* * *}$ represents value selected to compare.

TABLE 3: Fractionation of all active plants by different solvents inhibiting hyaluronidase enzyme activity of Pakistani Echis carinatus venom.

\begin{tabular}{|c|c|c|c|c|}
\hline \multirow{2}{*}{ Botanical names } & \multicolumn{4}{|c|}{ Percentage inhibition by different solvents (\%) } \\
\hline & $n$-hexane & Chloroform & Dichloromethane & Ethyl acetate \\
\hline Swertia chirayita (Roxb. ex Flem.) Karst. & 89 & 66 & -88 & 83 \\
\hline Terminalia arjuna (DC) Wight and Arn & 88 & -61 & 23 & 85 \\
\hline Rubia cordifolia thumb. & 87 & 64 & 83 & 51 \\
\hline Matthiola incana (L.) R.Br. & 86 & 50 & 86 & 59 \\
\hline
\end{tabular}

was added. Reaction mixture was incubated at $37^{\circ} \mathrm{C}$ for half an hour. At the end of this period, $2 \mathrm{~mL}$ of $\mathrm{NaOH}(0.2 \mathrm{M})$ solution was added and was further kept for 20 minutes at room temperature to halt the reaction and to confer stable yellow color to $p$-nitrophenol which absorbed maximally at $400 \mathrm{~nm}$ [37]. A standard curve of known concentrations of p-nitrophenol was constructed, and ALPase activity will be expressed as micromole of product released per minute [38]. To measure neutralizing potential of medicinal plants, plant extracts were preincubated with venom for $30 \mathrm{~min}$ at $37^{\circ} \mathrm{C}[31]$.

2.7. Fractionation of Active Medicinal Plants. All the active medicinal plants were fractioned by using four solvents: $n$ -hexane, chloroform, dichloromethane, and ethyl acetate
[39]. Fractions were evaporated, and the obtained fractions were again tested using the previously described assay method for hyaluronidases activity.

2.8. Phytochemical Screening. Phytochemical screening for secondary metabolites present in both the active medicinal plants and active plant fraction was performed according to standard procedures [40].

2.9. Statistical Analysis. All experimental data was presented as mean, whereas inhibition of enzyme activity was expressed in percentage by using Microsoft Excel, 2007. Student's $t$-test was used to compare the inhibition results to the standard reference with level of significance set at $p>0.5$. 


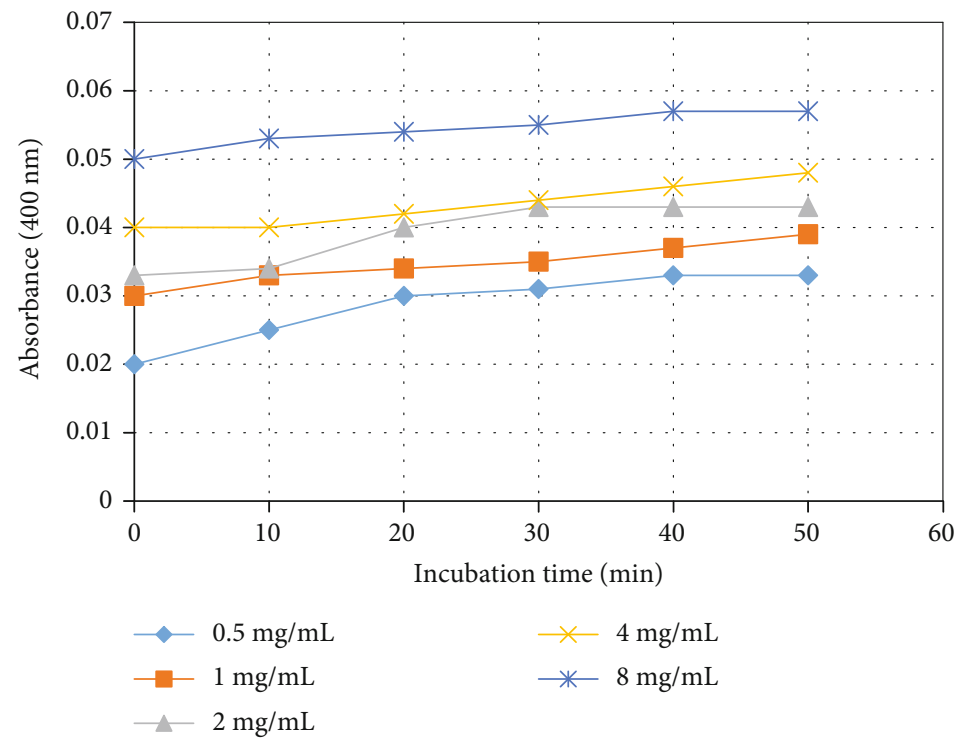

FIGURE 3: Screening of alkaline phosphatase enzymatic activity at different concentrations present in Echis carinatus venom.

TABle 4: Phytochemical analysis of active plant crude extracts evaluated as antivenom.

\begin{tabular}{|c|c|c|c|c|}
\hline Phytochemicals & $\begin{array}{c}\text { Swertia } \\
\text { chirayita } \\
\text { (Roxb. ex } \\
\text { Flem.) } \\
\text { Karst. }\end{array}$ & $\begin{array}{c}\text { Terminalia } \\
\text { arjuna } \\
\text { (DC) } \\
\text { Wight and } \\
\text { Arn }\end{array}$ & $\begin{array}{l}\text { Rubia } \\
\text { cordifolia } \\
\text { thumb. }\end{array}$ & $\begin{array}{c}\text { Matthiola } \\
\text { incana } \\
\text { (L.) R.Br. }\end{array}$ \\
\hline Alkaloids & + & + & + & + \\
\hline Flavonoids & + & + & + & + \\
\hline Fatty acids & - & - & - & - \\
\hline Steroids & + & + & + & + \\
\hline Phenols & + & + & + & + \\
\hline Tannins & + & + & + & + \\
\hline Glycosides & - & + & + & + \\
\hline Saponins & + & + & + & + \\
\hline Proteins & - & + & + & - \\
\hline Terpenoids & - & + & + & + \\
\hline Carbohydrate & - & + & - & + \\
\hline
\end{tabular}

Note: the + sign indicated about presence while the - sign depicted about absence.

\section{Results}

Results showed that hyaluronidase enzyme $(2-16 \mathrm{mg} / \mathrm{mL})$ of Echis carinatus venom was found to reduce turbidity of reaction mixture upon incubating for longer duration of time. The decrease in turbidity was observed in dose-dependent manner (Figure 1). Venom at the higher concentration $(8 \mathrm{mg} / \mathrm{mL})$ was found to remove turbidity completely and considered to show $100 \%$ enzyme activity at 10 minutes. Furthermore, kinetics data (Michaelis-Menten kinetics) were also obtained $\left(\mathrm{Km}=16 ; V_{\max }=0.023\right)$ to optimize the hyaluronidase assay (Figure 2). Results for fractionation of all active plants using four solvents showed $n$-hexane to be the most active fraction for all active plants, i.e., Swertia chirayita
TABle 5: Phytochemical analysis all active fractions of Swertia chirayita (Roxb. ex Flem.) Karst. and Terminalia arjuna Wight and Arn extracts.

\begin{tabular}{|c|c|c|c|c|}
\hline \multirow{2}{*}{ Phytochemicals } & \multicolumn{2}{|c|}{$\begin{array}{c}\text { Swertia chirayita } \\
\text { (Roxb. ex Flem.) Karst. }\end{array}$} & \multicolumn{2}{|c|}{$\begin{array}{l}\text { Terminalia arjuna } \\
\text { (DC) Wight and Arn }\end{array}$} \\
\hline & $\begin{array}{c}n \\
\text {-hexane }\end{array}$ & Ethyl acetate & $\begin{array}{c}n \\
\text {-hexane }\end{array}$ & Ethyl acetate \\
\hline Alkaloids & + & + & + & + \\
\hline Flavonoids & + & + & + & + \\
\hline Fatty acids & - & - & - & - \\
\hline Steroids & + & + & + & + \\
\hline Phenols & - & - & + & + \\
\hline Tannins & + & - & + & + \\
\hline Glycosides & + & + & - & + \\
\hline Saponins & + & + & + & + \\
\hline Proteins & - & - & - & - \\
\hline Terpenoids & + & - & - & + \\
\hline Carbohydrate & - & - & - & - \\
\hline
\end{tabular}

Note: the + sign indicated about presence while the - sign depicted about absence.

(Roxb. ex Flem.) Karst., Terminalia arjuna (DC) Wight and Arn, Matthiloa incana (L.) R.Br., and Rubia cordifolia Thumb. with inhibition percentages $89 \%, 88 \%, 84 \%$, and $86 \%$, respectively (Table 2). Details of fractionation have summarized in Table 3. Alkaline phosphatase activity was determined by measuring micromoles of $p$-nitrophenol (product) released per minute by the colorimetric assay. Despite of high Echis carinatus venom doses $(1-8 \mathrm{mg} / \mathrm{mL})$, very minute response $(0.057)$ was observed for triplicates within fifty minute incubation (Figure 3 ). Due to very less amount of alkaline phosphatase even at high venom doses which was undetectable, therefore, this assay was not performed further and rejected. 
TABle 6: Phytochemicals analysis all active fractions of Rubia cordifolia Thumb. and Matthiola incana (L.) R.Br. extracts.

\begin{tabular}{lcccc}
\hline Phytochemicals & \multicolumn{2}{c}{ Rubia cordifolia Thumb. } & \multicolumn{2}{c}{ Matthiola incana (L.) R.Br. } \\
Dichloromethane
\end{tabular}

Note: the + sign indicated about presence while the - sign depicted about absence.

Eighteen Pakistani medicinal plants were tested to evaluate inhibition potential against hyaluronidase enzyme of Pakistani Echis carinatus venom. Out of all plants, Matthiloa incana (L.) R.Br., Rubia cordifolia Thumb., Swertia chirayita (Roxb. ex Flem.) Karst., and Terminalia arjuna (DC) Wight and Arn inhibited 88\% $(p>0.5)$ and $88 \%(p>0.5)$ while Matthiloa incana (L.) R.Br. and Rubia cordifolia Thumb inhibited $86 \%(p>0.5)$ and $87 \%(p>0.5)$, respectively. Inhibition potential of all medicinal plants against hyaluronidase enzyme activity of Echis carinatus venom has been summarized in Table 2. Presence of phytochemicals in all active plants and their active fractions were analyzed by following standard protocols, and results have been summarized in Tables 4-6.

\section{Discussion}

Snakebite envenoming is a common issue in many developing countries, and mostly rural communities suffer its consequences. They use medicinal plants for pain relief. At present, the only ideal treatment for snakebite injury is the use of antisnake venom serum which is not easily available. It is costly and requires specific storage protocol. People with such injuries have to rush to the hospital for treatment which gives venom the time to cause neurotoxicity, hemorrhage, and local tissue damage that are not reversible in the victims. Also, antisnake venom serum has some side effects like anaphylactic reaction, serum sickness, and many other problems $[12,41]$. It is therefore necessary to find plant-based antidote to neutralize snake venom toxic effects. Use of medicinal plants is still a common practice by traditional healers as it is easily available natural resource and provides instant aid against snake envenoming $[42,43]$.

Echis carinatus is one the four deadliest snakes found in Pakistan. Its venom consists of many hydrolytic enzymes which acts together to spread toxins into its victim. Hyaluronidase enzyme being one of the toxic material degrade local/connective tissues and proteins which promote the diffusion of venom toxins resulting in cell damage, inflammation, reduced membrane viscosity, pathogenesis, and impaired immune system [44]. Severity of cell degradation and necrosis also depends on amount of venom injected [45]. Extracellular matrix degradation is a continuous process in victim; therefore, antisnake venom serum could not inhibit local tissue damage completely [44].

Hyaluronidase activity was measured by its turbidityreducing property, and its inhibition was evaluated by medicinal plants. Terminalia arjuna (DC) Wight and Arn (Combretaceae) and Rubia cordifolia Thumb. (Rubiaceae) neutralized hyaluronidase enzyme activity of Echis carinatus venom with $p>0.5$. Similarly in previous studies, medicinal plants from Combretaceae and Rubiaceae family have been proved to inhibit hyaluronidase enzyme activity in Naja nigricollis [46]. Swertia chirayita (Roxb. ex Flem.) Karst. and Matthiloa incana (L.) R.Br. also showed antihyaluronidase activity $(p>0.5)$ which was possible as medicinal plants are packed with inhibitory compounds like alkaloids, antioxidants, flavonoids, glycosides, glycosaminoglycans, oligosaccharides, fatty acids, polysaccharides, terpenoids, and other compounds with therapeutic properties [47]. Previous researches have showed many plants with potential to inhibit snake venom hyaluronidase activity. These plants include Mangifera indica, Andrographis paniculata, Carisssa spinarum, and Azima tetracantha Lam used against Daboia russellii, Naja naja, Bungarus caeruleus , and Vipera russelli, respectively [48-51].

Alkaline phosphatases along with other enzymes (like phospholipases and proteases) of snake venom assist in cell necrosis which lead to liberation of nucleic acids (DNA and RNA) and eventually release adenosine which cause detrimental damage to human body $[30,52]$. Alkaline phosphatase enzyme is less studied, and thus their role is not specified. In current study, alkaline activity was very minute and unmeasurable in spite of high venom doses; therefore, this assay was dropped. It was supported by previous studies which elaborated that alkaline phosphatase enzymes have been found more in snakes of Elapidae and Crotalidae than in venom of Viperidae snakes $[17,53]$.

Janardhan et al. [50] reported that $n$-hexane extract of Azima tetracantha Lam. inhibited hylauronidase activity in 
Vipera russelli whereas ethyl acetate extract inhibited Bungarus caeruleus hyaluronidase enzyme activity. Similarly, in the current study, fractionation data showed that $n$-hexane fractions of all active plants inhibited hyaluronidase activity, whereas some of ethyl acetate fractions were also able to neutralize enzyme activity.

\section{Conclusions}

Present study on toxic enzymes of Pakistani Echis carinatus venom revealed that traditionally used medicinal plants have great potential to inhibit hyaluronidase activity due to combined action of phytochemicals. Neutralizing activity of medicinal plants could be studied further on animals and other in vitro pharmacological testings in order to develop a natural or synthetic antidote from indigenous medicinal plants against snakebite envenoming.

\section{Data Availability}

Upon request data may be provided by the first author (Syeda Fatima: fatimaasyed90@gmail.com).

\section{Conflicts of Interest}

Authors declared no conflict of interest.

\section{Acknowledgments}

Authors would like to thank the National Institute of Health, Islamabad (NIH), Pakistan, for provision of Echis carinatus venom. Moreover, authors are cordially thankful to the Dr. Muhammad Hassham Hassan Bin Asad (KFU, Russia; CUI, Pakistan) for his sincere efforts to publish this work.

\section{References}

[1] H. E. Nonga and A. Haruna, "Assessment of human-snake interaction and its outcomes in Monduli District, northern Tanzania," Tanzania Journal of Health Research, vol. 17, no. 1, pp. 1-12, 2015.

[2] J. Longbottom, F. M. Shearer, M. Devine et al., "Vulnerability to snakebite envenoming: a global mapping of hotspots," The Lancet, vol. 392, no. 10148, pp. 673-684, 2018.

[3] R. A. Harrison, A. Hargreaves, S. C. Wagstaff, B. Faragher, and D. G. Lalloo, "Snake envenoming: a disease of poverty," PLOS Neglected Tropical Diseases, vol. 3, no. 12, p. e569, 2009.

[4] World Health Organization, Guidelines for the management of snake-bites, WHO Regional Office in South-East Asia, 2010.

[5] D. A. Warrell and J. M. Gutérrez, "New approaches and technologies of venomics to meet the challenge of human envenoming by snakebites in India," Indian Journal of Medical Research, vol. 138, no. 1, pp. 38-59, 2013.

[6] K. Nagaraju and N. Kannappan, "Survey on patern of snake bite cases admitted in South Indian Tertary Care Hospitals," International Journal of Pharmaceutical Sciences and Research, vol. 6 , no. 10, p. 4362, 2015.

[7] G. Parveen, F. Khan M, H. Ali, T. Ibrahim, and R. Shah, "Determination of lethal dose $\left(\mathrm{LD}_{50}\right)$ of venom of four different poisonous snakes found in Pakistan," Biochemistry \& Molecular Biology Journal, vol. 3, no. 3, pp. 1-5, 2017.
[8] World Health Organisation, Rabies and Envenomings: A Neglected Public Health Issue, World Health Organisation, Geneva, 2007.

[9] M. H. H. B. Asad, M. T. Razi, T. Khan et al., "Coagulopathies in Naja naja karachiensis (black Pakistan cobra) bites and its effect on coagulation tests upon storage of platelet poor plasma," Acta poloniae Pharmaceutica drug research, vol. 69, pp. 1031-1034, 2012.

[10] A. N. Nanjaraj Urs, M. Yariswamy, V. Joshi et al., "Local and systemic toxicity of Echis carinatus venom: neutralization by Cassia auriculata L. leaf methanol extract," Journal of Natural Medicines, vol. 69, no. 1, pp. 111-122, 2015.

[11] I. Chatterjee, A. K. Chakravarty, and A. Gomes, "Daboia russellii and Naja kaouthia venom neutralization by lupeol acetate isolated from the root extract of Indian sarsaparilla Hemidesmus indicus R.Br," Journal of Ethnopharmacology, vol. 106, no. 1, pp. 38-43, 2006.

[12] D. Warrell, Clinical toxicology of snakebite in Asia. Handbook of clinical toxicology of animal venoms and poisons, CRC Press, Boca Raton, USA, 1995.

[13] T. Matsui, Y. Fujimura, and K. Titani, "Snake venom proteases affecting hemostasis and thrombosis," Biochimica et Biophysica Acta (BBA)-Protein Structure and Molecular Enzymology, vol. 1477, no. 1-2, pp. 146-156, 2000.

[14] R. Guerranti, A. Cortelazzo, N. S. Hope-Onyekwere et al., "In vitro effects of Echis carinatus venom on the human plasma proteome," Proteomics, vol. 10, no. 20, pp. 3712-3722, 2010.

[15] K. S. Girish, R. Shashidharamurthy, S. Nagaraju, T. V. Gowda, and K. Kemparaju, "Isolation and characterization of hyaluronidase a "spreading factor" from Indian cobra (Naja naja) venom," Biochimie, vol. 86, no. 3, pp. 193-202, 2004.

[16] M. C. A. Rodrigues, L. H. S. Guimarães, J. L. Liberato, M. L. T. de Moraes Polizeli, and W. F. Santos, "Acid and alkaline phosphatase activities of a fraction isolated from Parawixia bistriata spider venom," Toxicon, vol. 47 , no. 8, pp. $854-858$, 2006.

[17] B. L. Dhananjaya and C. J. D'Souza, “The pharmacological role of phosphatases (acid and alkaline phosphomonoesterases) in Snake venoms related to release of purines - a multitoxin," Basic \& Clinical Pharmacology \& Toxicology, vol. 108, no. 2, pp. 79-83, 2011.

[18] M. I. Alam, "Inhibition of toxic effects of viper and cobra venom by Indian medicinal plants," Pharmacology \& Pharmacy, vol. 5, no. 8, pp. 828-837, 2014.

[19] M. I. Alam and A. Gomes, "Snake venom neutralization by Indian medicinal plants (Vitex negundo and Emblica officinalis) root extracts," Journal of Ethnopharmacology, vol. 86, no. 1, pp. $75-80,2003$.

[20] A. Hussain, M. Zia, and B. Mirza, "Cytotoxic and antitumor potential of Fagonia cretica L.," Turkish journal of biology, vol. 31, no. 1, pp. 19-24, 2007.

[21] S. Pukrittayakamee, D. A. Warrell, V. A. J. Desakorn, A. J. McMichael, N. J. White, and D. Bunnag, "The hyaluronidase activities of some southeast Asian snake venoms," Toxicon, vol. 26, no. 7, pp. 629-637, 1988.

[22] U K Laemmli, U K, "Cleavage of structural proteins during the assembly of the head of bacteriophage T4," Nature, vol. 227, no. 5259, pp. 680-685, 1970.

[23] I. M. Shanono, Y. Y. Muhammad, A. I. Kankara, and B. G. Kurfi, "Isolation and enzymatic characterization of the snake venom hyaluronidase from Naja melanoleuca (Forest cobra) 
venom," Journal of Entomology and Zoology Studies, vol. 7, no. 4, pp. 1248-1252, 2019.

[24] M. A. Butt, M. Ahmad, A. Fatima et al., "Ethnomedicinal uses of plants for the treatment of snake and scorpion bite in northern Pakistan," Journal of Ethnopharmacology, vol. 168, pp. 164-181, 2015.

[25] S. Z. Husain, R. N. Malik, M. Javaid, and S. Bibi, "Ethonobotanical properties and uses of medicinal plants of Morgah biodiversity park, Rawalpindi," Pakistan Journal of Botany, vol. 40, no. 5, pp. 1897-1911, 2008.

[26] S. K. Basha and G. sudarsanam, "Traditional use of plants against snakebite in Sugali tribes of Yerramalais of Kurnool district, Andhra Pradesh, India," Asian Pacific Journal of Tropical Biomedicine, vol. 2, no. 2, pp. S575-S579, 2012.

[27] R. P. Samy, M. M. Thwin, P. Gopalakrishnakone, and S. Ignacimuthu, "Ethnobotanical survey of folk plants for the treatment of snakebites in southern part of Tamilnadu, India," Journal of Ethnopharmacology, vol. 115, no. 2, pp. 302-312, 2008.

[28] M. T. Naidu, N. C. Babu, and M. Venkaiah, "Ethnic remedies against snake bite from Kotia hills of Vizianagaram district, Andhra Pradesh, India," Indian Journal of Natural Products and Resources, vol. 4, no. 2, pp. 194-196, 2013.

[29] T. Thirumalai, E. K. Elumalai, S. V. Therasa, B. Senthilkumar, and E. David, "Ethnobotanical survey of folklore plants for the treatment of jaundice and snakebites in Vellore districts of Tamilnadu, India," Ethnobotanical leaflets, vol. 14, pp. 529536, 2010.

[30] M. Tahir Razi, M. H. H. B. Asad, T. Khan et al., "Antihaemorrhagic potentials ofFagonia creticaagainstNaja naja karachiensis(black Pakistan cobra) venom," Natural Product Research, vol. 25, no. 20, pp. 1902-1907, 2011.

[31] M. H. H. B. Asad, G. Murtaza, and I. Hussain, "A remedial approach for Naja naja karachiensis envenomation: enzymatic assay for alkaline phosphatase activity in extracts of local plants of Pakistan," Pakistan Journal of Zoology, vol. 46, no. 6, pp. 1775-1781, 2014.

[32] K. S. Kumar and D. Bhowmik, "Traditional medicinal uses and therapeutic benefits of Momordica charantia Linn," International Journal of Pharmaceutical Sciences Review and Research, vol. 4, no. 3, pp. 23-28, 2010.

[33] A. Dey and J. N. De, "Traditional use of plants against snakebite in Indian subcontinent: a review of the recent literature," African Journal of Traditional, Complementary and Alternative Medicines, vol. 9, no. 1, pp. 153-174, 2012.

[34] S. R. Baquar, Medicinal and poisonous plants of Pakistan, Printas Karachi Pakistan, 1st edition, 1989.

[35] K. S. Kumar, B. Debjit, and C. Margret, "Swertia chirayita: a traditional herb and its medicinal uses," Journal of Chemical and Pharmaceutical Research, vol. 2, no. 1, pp. 262-266, 2010.

[36] A. Jabeen, S. Rani, M. Ibrahim, and A. S. Mohammad, "A review on Lepidium sativum," Indo American Journal of Pharmaceutical Sciences, vol. 4, no. 8, pp. 2223-2227, 2017.

[37] M. K. K. Yap, N. H. Tan, and S. Y. Fung, "Biochemical and toxicological characterization of Naja sumatrana (equatorial spitting cobra) venom," Journal of Venomous Animals and Toxins Including Tropical Diseases, vol. 17, no. 4, pp. 451-459, 2011.

[38] S. Ushanandini, S. Nagaraju, K. H. Kumar et al., “The antisnake venom properties of Tamarindus indica(leguminosae) seed extract," Phytotherapy Research: An International Journal Devoted to Pharmacological and Toxicological Evaluation of Natural Product Derivatives, vol. 20, no. 10, pp. 851-858, 2006.
[39] B. C. VanWagenen, R. Larsen, J. H. Cardellina, D. Randazzo, Z. C. Lidert, and C. Swithenbank, "Ulosantoin, a potent insecticide from the sponge Ulosa ruetzleri," The Journal of Organic Chemistry, vol. 58, no. 2, pp. 335-337, 1993.

[40] S. Fatima, T. Javed, S. Khalid et al., "Evaluation of different Pakistani medicinal plants for inhibitory potential against Echis carinatus induced phospholipase $\mathrm{A}_{2}$ toxicity," Pakistan Journal of Pharmaceutical Sciences, vol. 32, no. 5, pp. 22692277, 2019.

[41] P. Corrigan, F. E. Russel, and J. Wainchat, Toxins of animal, plant and microbial, P. Rosenburg, Ed., Pergamon Press, New York, 1988.

[42] I. K. Makhija and D. Khamar, "Anti-snake venom properties of medicinal plants," Der Pharmacia Lettre, vol. 2, no. 5, pp. 399-411, 2010.

[43] K. S. Girish and K. Kemparaju, "The magic glue hyaluronan and its eraser hyaluronidase: a biological overview," Life Sciences, vol. 80, no. 21, pp. 1921-1943, 2007.

[44] J. P. Chippaux, Snake venoms and envenomations, Krieger Publishing Company, 2006.

[45] M. Molander, L. Nielsen, S. Søgaard et al., "Hyaluronidase, phospholipase $\mathrm{A}_{2}$ and protease inhibitory activity of plants used in traditional treatment of snakebite-induced tissue necrosis in Mali, DR Congo and South Africa," Journal of Ethnopharmacology, vol. 157, pp. 171-180, 2014.

[46] E. Bala, R. Hazarika, P. Singh, M. Yasir, and R. Shrivastava, “A biological overview of Hyaluronidase: a venom enzyme and its inhibition with plants materials," Materials Today: Proceedings, vol. 5, no. 2, pp. 6406-6412, 2018.

[47] B. L. Dhananjaya, F. Zameer, K. S. Girish, and C. J. DSouza, "Anti-venom potential of aqueous extract of stem bark of Mangifera indica L. against Daboia russellii (Russell's viper) venom," Indian Journal of Biochemistry and Biophysics, vol. 48, no. 3, pp. 175-183, 2011.

[48] K. Gopi, K. Renu, M. Raj, D. Kumar, and B. Muthuvelan, "The neutralization effect of methanol extract of Andrographis paniculata on Indian cobra Naja naja snake venom," Journal of Pharmacy Research, vol. 4, no. 4, pp. 1010-1012, 2011.

[49] B. Janardhan, V. M. Shrikanth, K. K. Mirajkar, and S. S. More, "In vitro anti-snake venom properties of Carisssa spinarum Linn leaf extracts," Journal of Herbs, Spices \& Medicinal Plants, vol. 21, no. 3, pp. 283-293, 2014.

[50] B. Janardhan, V. M. Shrikanth, K. K. Mirajkar, and S. S. More, "In vitro screening and evaluation of antivenom phytochemicals from Azima tetracantha Lam. leaves against Bungarus caeruleus and Vipera russelli," Journal of Venomous Animals and Toxins including Tropical Diseases, vol. 20, no. 1, pp. 18, 2014.

[51] B. Janardhan, V. M. Shrikanth, V. S. More, G. Melappa, F. Zameer, and S. S. More, “_Bungarus caeruleus_venom neutralization activity of_Azima tetracantha_Lam. Extract," Heliyon, vol. 5, no. 7, article e02163, 2019.

[52] E. Alirol, S. K. Sharma, H. S. Bawaskar, U. Kuch, and F. Chappuis, "Snake bite in South Asia: a review," PLoS Neglected Tropical Diseases, vol. 4, no. 1, p. e603, 2010.

[53] S. D. Aird, "Taxonomic distribution and quantitative analysis of free purine and pyrimidine nucleosides in snake venoms," Comparative Biochemistry and Physiology Part B: Biochemistry and Molecular Biology, vol. 140, no. 1, pp. 109-126, 2005. 